\title{
Differential Gene Function and Physico-Chemical Properties of Sugar Beet Chromatin
}

\author{
Seehy M. A ${ }^{1}$ and Amira M. E. Khatab ${ }^{2}$
}

\begin{abstract}
The present investigation aims at studying the possibility to use the physico-chemical properties of the purified chromatin as an indicator for transcriptional activity. In order to achieve such a purpose, five different breeding materials of sugar beet are selected and used. These materials are: 1, 2, 3, 4 and 5. Temperature of melting (Tm) estimated in ${ }^{\circ} \mathrm{C}$ and hyperchromicity were estimated at $260 \mathrm{~nm}$ and $280 \mathrm{~nm}$, as well as the chemical compositions of chromatin; DNA; Histones; non histones and total proteins. The chemical compositions, relative to DNA showed that different chemical compositions; temperature of melting; hyperchromicity, and repressed fraction of genome were obtained, giving a strong evidence that these molecular biomarkers might be used in breeding program of sugar beet. In conclusion the present investigation recommends the use of physico-chemical properties as a molecular biomarker to measure the transcriptional activity of plant materials.
\end{abstract}

\section{INTRODUCTION}

The main goal of sugar beet breeders is to develop sugar beet varieties with high root yield and high sugar content, better extraction yield (juice purity), higher seed germination percentages; lower tendency to "bolt" and higher resistance to leaf diseases. However, Sugar Beet Breeding Program is concentrated on collecting different sugar beet breeding materials from different countries to achieve this goal. Sugar beet breeding materials has been exposed to different evaluating and testing experiment (Khatab, 2001).

The identification of sugar beet varieties and/or genotypes is a fruitful approach and it benefits the farmer who would thus receive a product that provides the expected agronomic characters and also the correct identification. Schondelmaier and Jung (1997) used twenty-four marker loci representing each of the nine linkage groups of sugar beet (Beta vulgaris) they assigned to nine previously produced primary trisomics. Single-copy RFLP probes were hybridized with filterbound DNA of the trisomics. The auto radiographs were scanned and analysed by demsitometuric methods. For the first time each of the linkage groups could unequivocally be assigned to one sugar beet chromosome. A standard nomenclature of the 9 chromosomes of sugar beet was suggested and discussed with respect to previous numbering systems.

The main objective of the present research work is to use Physico-chemical properties of purified chromatin isolated from leaves as a molecular marker.

\section{MATERIALS AND METHODS}

\section{Materials}

Five botanical genotypes of sugar beet were kindly supplied by Sugar Crops Research Institute, Agricultural Research Center (ARC).

\section{Methods}

\subsection{Sugar beet Cultivation:}

Seeds were cultivated in pots. For each genotype 20 pots were used. After two months of cultivation, leaves of plants were cut and subjected to the various analyses.

\subsection{Physico-chemical properties of chromatin:}

Leaves (about $100 \mathrm{~g}$ from each genotype) were collected and immediately frozen until usage.

\subsection{A. Extraction and purification of chromatin:}

The chromatin was isolated by the method described by Fellenberg \& Schomer (1975); Seehy (1980); Seehy et al., (1990) and Abdel-Fattah (2002). The frozen leaf tissues were ground in a chilled mortar with small amount of the following buffer:

\section{$0.075 \mathrm{M} \mathrm{NaCl}$}

$0.01 \mathrm{M}$ Na-citrate

0.01M Tris-HC1, pH8.0

Then, the grounds were homogenized in the same buffer ( $3 \mathrm{ml}$ buffer for each gram material) with highspeed blender (6000 rounds per minute) for 2 minutes. The homogenate was filtered through three layers of nylon mesh (pore size of $50 \mu$ ). The filtrate was saved while the residue was again homogenized in the same buffer and filtered. The residue was discarded and the combined filters were centrifuged for 30 minutes at $7000 \mathrm{xg}$. The supernatant was discarded and the pellet was resuspended in the same buffer, and centrifuged at $15000 \mathrm{xg}$ for 10 minutes. The last step was repeated four times using the same amount of buffer and centrifugal force. The pellet was resuspended in the following buffer:

\footnotetext{
${ }^{1}$ Dept. Genetics Fac. of Agric. Alexandria University.

${ }^{2}$ Dept. of Biology Fac. of Girls Education Univ. of Elmajmaah.

Kingdom of Saudi Arabia.

Received December 13, 2011, Accepted December 28, 2011.
} 


\section{$0.03 \mathrm{M} \mathrm{NaCl}$}

\section{$0.01 \mathrm{M}$ Tris- $\mathrm{HCl}, \mathrm{pH} 8.0$,}

and centrifuged for 10 minutes at $15000 \mathrm{xg}$.

For chromatin extraction, the recovered pellet was gently stirred for 30 minutes in $4 \mathrm{ml}$ of $1 \mathrm{MNaCl}$, 0.01MTris- $\mathrm{HCl}, \mathrm{pH} 7.2$ buffer and the mixture was kept over-night at $2^{\circ} \mathrm{C}$. Then, the chilled mixture was centrifuged at $32000 \mathrm{xg}$ for 30minutes and the supernatant containing the chromatin was kept in clean vial at $4^{\circ} \mathrm{C}$.

Chromatin was purified by filtration through Sephadex G-25 Fine using the $1 \mathrm{MNaCl}$ buffer. Using the ultraviolet spectrophotometer (Shimadzuv-240) the purity of chromatin preparations was checked by the following criteria:

1- Absorbance at $260 \mathrm{~nm} /$ absorbance at $240=$ or more than 1.5

2- Absorbance at $250 \mathrm{~nm} /$ absorbance at $260=0.8-0.9$

3- Absorbance at $280 \mathrm{~nm} /$ absorbance at $260=0.5-0.6$

4- Absorbance at $320 \mathrm{~nm} /$ absorbance at 260 less than $10 \%$

When purified chromatin showed adequate ultraviolet absorption spectrum, then it was dialyzed three times at $0-2^{\circ} \mathrm{C}$ against one liter of $0.0014 \mathrm{M} \mathrm{NaCl}$, $0.00025 \mathrm{M}$ tris-HCl, $\mathrm{PH} 7.2$ buffer.

\subsection{B. Estimation of melting temperature (TM value):}

Heating was carried out in diluted saline solution (0.0014M NaCl, 0.00025 M Tris -HCl, pH7.2). Melting temperature of the chromatin was recorded at $260 \mathrm{~nm}$ as well as $280 \mathrm{~nm}$ by ultraviolet spectrophotometer Schimadzu uv-160, while heating was done by temperature program controller, Schimadzu TB-85, giving a temperature rate of $1^{\circ} \mathrm{C} / \mathrm{min}$. in order to estimate $\mathrm{Tm}$ - value, the procedure was the same as that described by Bonner et al., (1968); Seehy et al., (1990) and Abdel-Fattah (2002). From each extraction two estimations were calculated. The absorbance of all investigated samples was recorded every minute at 260 $\mathrm{nm}$ as well as at $280 \mathrm{~nm}$. The relative absorbance was calculated as described by Seehy (1980); Seehy et al. (1990). Relative Absorbance $=\mathrm{AG} / \mathrm{A} 50^{\circ} \mathrm{C}$, where $\mathrm{AG}$ is the absorbance at a given temperature and $\mathrm{A} 50^{\circ} \mathrm{C}$ is the absorbance at $50^{\circ} \mathrm{C}$.

\subsection{Total proteins, non-histon, DNA}

Histone and non- histone proteins

Extraction of histones was carried out from purified chromatin with $\mathrm{HCl}$ by using $10 \mathrm{ml}$ chromatin in each analysis. Chromatin solution was acidified by adding $4 \mathrm{ml}$ of $5 \mathrm{HCl}$ (kept at $2{ }^{\circ} \mathrm{C}$ for 12 hours), to reach $0.4 \mathrm{~m}$
$\mathrm{M} \mathrm{HCl}$, then centrifuged at $6000 \mathrm{xg}$ for 10 minutes at $0^{\circ} \mathrm{C}$. The supernatant was saved while the sediment was washed by $0.4 \mathrm{M} \mathrm{HCl}$ for $30 \mathrm{~min}$. at $0^{\circ} \mathrm{C}$, then it was again centrifuged at $6000 \mathrm{xg}$ for 10 minutes at $0^{\circ} \mathrm{C}$. The combined supernatants were neutralized with $\mathrm{NaOH}$ and the $\mathrm{PH}$ adjusted at 7.2. The determination of histones was done by the method of Lowry et al (1951).

Non- histone proteins were calculated as the difference between the total proteins and histones. Total proteins, histones and non-histone proteins were determined as $\mu \mathrm{g} / \mathrm{ml}$ chromatin and then, the different proteins were calculated as relative to the DNA.

\section{RERSULTS}

As shown in Table (1) the tested genotype 1 was proven to display the higher value of root weight (1.530) followed by the genotype 2 . However the genotype 1 showed high percent of sucrose (18.2\%), giving a good evidence that this genotype is considered to be a suitable source for selection and/or for evaluative purpose in sugar beet breeding program.

\section{Physico-chemical properties of chromatin:}

Figure (1) illustrates the ultraviolet absorption spectrum of purified chromatin isolated from the genotypes 1, 2, 3, 4 and 5. All coefficients of absorbance of chromatin were in the standard ranges for the five genotypes of Beta vulgaris under study. Therefore, the chromatins of these genotypes were proven to be pure enough to subject for testing the melting temperature.

Table (3) and Figure (2) represent the melting profiles and the Tm values for each chromatin of the five genotypes of Beta vulgaris under study.

For each chromatin type, melting profiles were applied at $260 \mathrm{~nm}$ and $280 \mathrm{~nm}$ wave lengths. As shown in Table (3), the Tm values at $260 \mathrm{~nm}$ ranged from $72.5^{\circ} \mathrm{C}$ for genotype $\mathrm{C} 4612$ and $77{ }^{\circ} \mathrm{C}$ for genotype C39. At $280 \mathrm{~nm}$, the $\mathrm{Tm}$ values ranged from $74.5^{\circ} \mathrm{C}$ for genotype $\mathrm{C} 4612$ to $80.5^{\circ} \mathrm{C}$ for genotype $\mathrm{C} 31 / 6$. Also, $\Delta \mathrm{Tm}$ values were found to be different from one genotype to another and ranged from $1{ }^{\circ} \mathrm{C}$ for genotype $\mathrm{C} 39$ to $6^{\circ} \mathrm{C}$ for genotype $\mathrm{C} 31 / 6$.

On the other hand, the amounts of total proteins; histones and non-histones proteins were estimated in the purified chromatin of the five genotypes under study (Table, 2) and it represents non-histones \% of total proteins of the purified chromatin for the five studied genotypes of Beta vulgaris. 
Table 1. Botanical genotypes of sugar beet tested in this work

\begin{tabular}{cccccc}
\hline Genotypes & Origin & Ploidy levels & Seed type & $\begin{array}{c}\text { Root } \\
\text { weight }\end{array}$ & $\begin{array}{c}\text { Sucrose } \\
\text { percentage }\end{array}$ \\
\hline $\mathbf{1}$ & U.S.A. (California) & Diploid & Polygerm & 0.830 & 18.4 \\
\hline $\mathbf{2}$ & U.S.A. (California) & Diploid & Polygerm & 0.850 & 17.9 \\
\hline $\mathbf{3}$ & U.S.A. (California) & Diploid & Polygerm & 0.770 & 17.5 \\
\hline $\mathbf{4}$ & U.S.A. (California) & Diploid & Polygerm & 1.530 & 18.2 \\
\hline $\mathbf{5}$ & U.S.A. (California) & Diploid & Polygerm & $\mathbf{1 . 1 0 0}$ & $\mathbf{1 7 . 4}$ \\
\hline
\end{tabular}
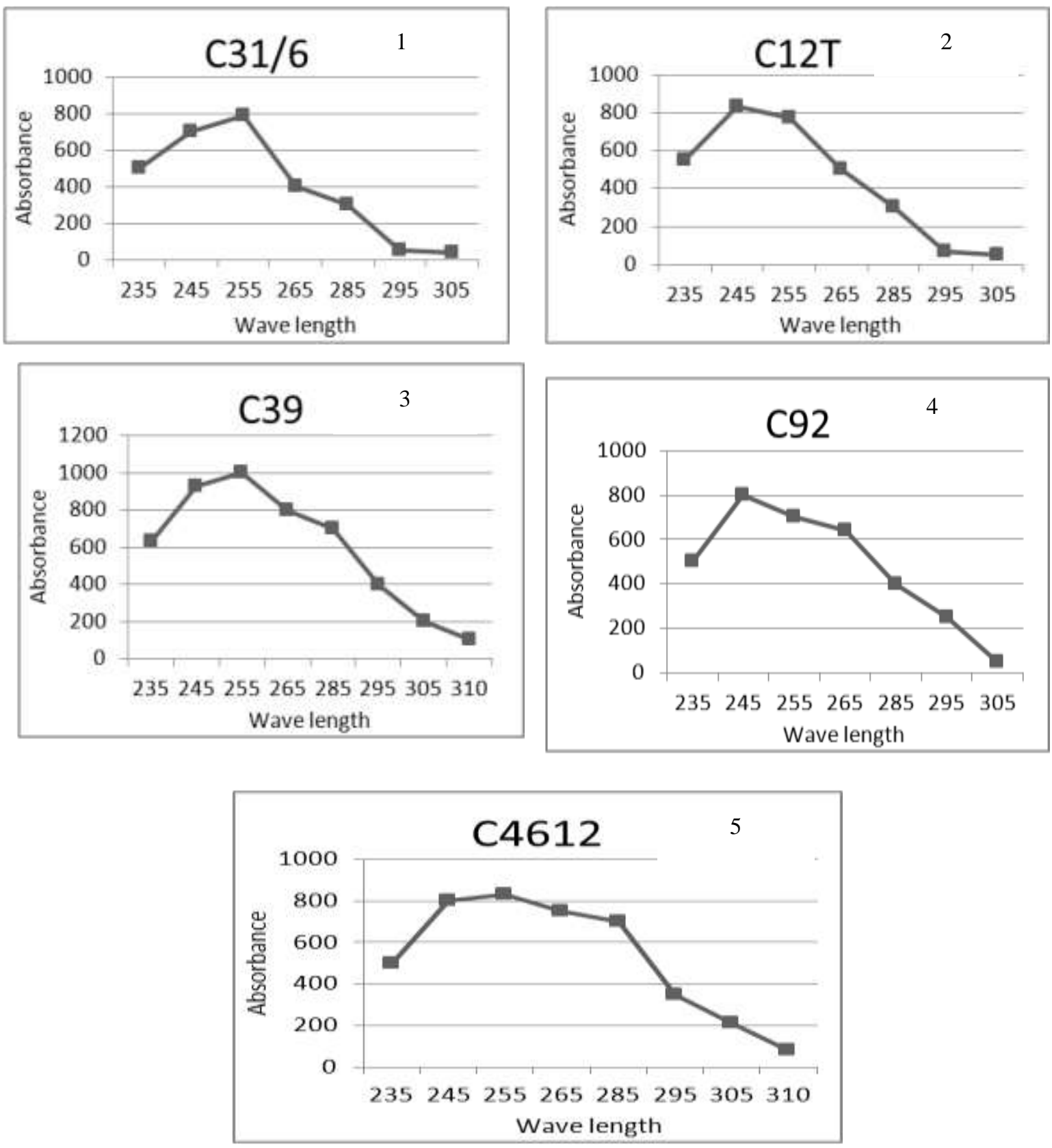

Figure 1. Ultraviolet absorption spectra of purified chromatin isolated from genotypes 
Table 2. *Chemical compositions of ** purified chromatin isolated from the tested genotypes Genotypes DNA Total proteins Histones Non-Histones Acidic proteins \% of total

\begin{tabular}{cccccc}
\hline 1 & 152 & 222 & 148 & 74 & proteins \\
\hline 2 & 210 & 383 & 219 & 164 & $33 \%$ \\
\hline 3 & 162 & 201 & 170 & 31 & $43 \%$ \\
\hline 4 & 190 & 411 & 220 & 191 & $46 \%$ \\
\hline 5 & 130 & 301 & 150 & 151 & $50 \%$ \\
\hline
\end{tabular}

* $\mu \mathrm{g} / \mathrm{ml}$ chromatin

** Chromatin soluble in $1 \mathrm{M} \mathrm{NaCl}, \mathrm{PH} 7.2$

Table 3. Temperature of melting ( $\mathrm{Tm}$ value)of chromatin isolated from the tested genotype at $260 \mathrm{~nm} \& 280 \mathrm{~nm}$

\begin{tabular}{ccccc}
\hline Genotype & Tm260 & Tm280 & $\Delta$ Tm & Hyperchromicity \\
\hline 1 & 74.5 & 80.5 & 6 & $33.40 \%$ \\
\hline 2 & 74.5 & 76.5 & 2 & $28.10 \%$ \\
\hline 3 & 77 & 78 & 1 & $40 \%$ \\
\hline 4 & 74.5 & 77 & 2.5 & $46 \%$ \\
\hline 5 & 72.5 & 74.5 & 2 & $41.40 \%$ \\
\hline
\end{tabular}
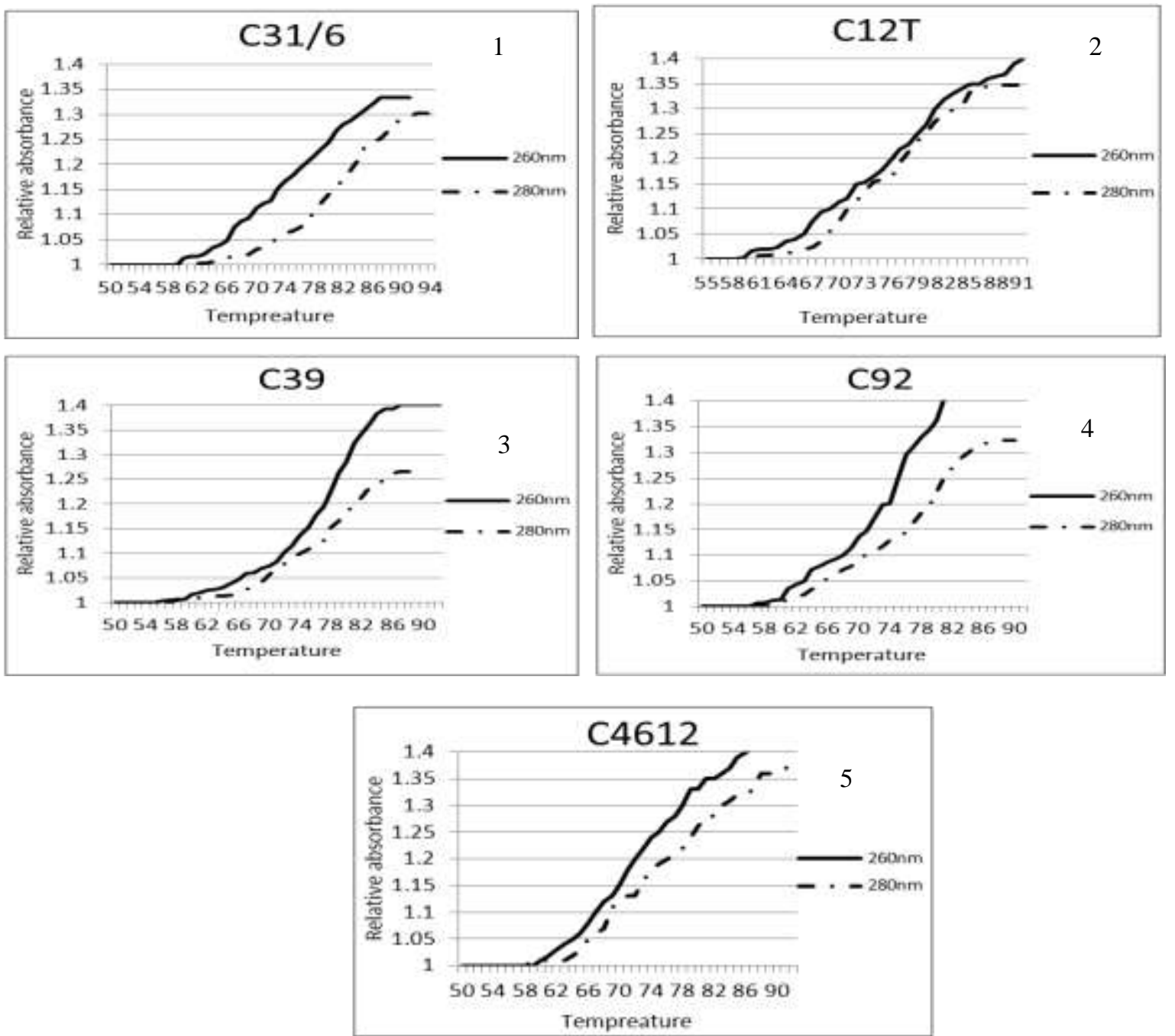

Figure 2. Melting profiles of chromatin at wave length $260 \&$ 28and melting was carried out in diluted saline solution $(0.0014 \mathrm{M} \mathrm{NaCl}$ 
Table (4) represents the chemical composition of purified chromatin relative to DNA isolated from the tested genotypes.

The repressed fraction of genome ranged from 74 to $85.70 \%$ for genotypes $\mathrm{C} 4612$ and C92; respectively, while the active fraction of genome ranged from 14.29 to 26\% for genotypes C92 and C4612; respectively, Table (5).

\section{DISCUSSION}

The present investigation aims at studying a specific molecular marker (i.e. physico-chemical properties of the purified chromatin as an indicator for transcriptional activity)

\section{Physico-chemical properties:}

The present investigation revealed that sugar beet leaves are a good source for chromatin. In addition, the method used was found to be successful for chromatin isolation.

Ultraviolet absorption spectra of all used samples of chromatin were shown to be acceptable. Melting of chromatin was carried out at $260 \mathrm{~nm}$ as well as $280 \mathrm{~nm}$ and showed differences in melting temperature of chromatin isolated from different genotypes, giving an evidence that transcriptional activity of chromatin was different Tm-value ranged from 72.5 to $77^{\circ} \mathrm{C}$ at $260 \mathrm{~nm}$ and at 280 it ranged from 74.5 to $80.5^{\circ} \mathrm{C} \mathrm{nm}$. $\Delta \mathrm{Tm}(280-$ 260) ranged from 1 to $6^{\circ} \mathrm{C}$.

Table 4.*Chemical compositions of ** purified chromatin isolated from the tested genotypes (Relative to DNA)

\begin{tabular}{ccccc}
\hline Genotype & DNA & Total proteins & Histones & Non-Histones \\
\hline $\mathbf{1}$ & 1 & 1.46 & 1.07 & 0.39 \\
\hline $\mathbf{2}$ & 1 & 1.823 & 1.042 & 0.78 \\
\hline $\mathbf{3}$ & 1 & 1.24 & 1.049 & 0.19 \\
\hline $\mathbf{4}$ & 1 & 2.16 & 1.15 & 1.005 \\
\hline $\mathbf{5}$ & 1 & 2.16 & 1 & 1.16 \\
\hline
\end{tabular}

*Relative to DNA

**Chromatin soluble in $1 \mathrm{M} \mathrm{NaCl}, \mathrm{PH} 7.2$

Table 5. Repressed and Active fraction of genome (RFG) \& (AFG), (Bonner et al, 1968 and Seehy et al, 1990)

\begin{tabular}{ccc}
\hline Genotype & RFG & AFG \\
\hline $\mathbf{1}$ & 79.2 & 20.8 \\
\hline $\mathbf{2}$ & 77.18 & 22.814 \\
\hline $\mathbf{3}$ & 77.70 & 22.29 \\
\hline $\mathbf{4}$ & 85.70 & 14.29 \\
\hline $\mathbf{5}$ & 74 & 26 \\
\hline
\end{tabular}

Seehy et al. (1990) reported that an alteration of $0.5 \pm \pm^{0} \mathrm{C}$ in $\mathrm{Tm}$-value is considered to be a significant difference. A comparison of Tm-values at $260 \mathrm{~nm}$ and $280 \mathrm{~nm}$ makes it possible to differentiate the cohesion of hydrogen bonds in deoxyribonucleic acid regions rich in adenine-thymine and guanine-cytosine, since the former more strongly absorb the wave length $260 \mathrm{~nm}$, while the latter absorb the wave length $280 \mathrm{~nm}$ more strongly, (Fellenberg, 1974 and Seehy, et al. 1990).

Data obtained from the chemical composition of purified chromatin relative to DNA showed that the genotype C92 displayed histones higher than that of other genotypes while the genotype C4612 represents the lowest value of histones. The tested genotypes could be arranged, according to the transcriptional activity based upon non-histone proteins (relative to DNA) would be arranged as follows: C4612 > C92 > C12T > $\mathrm{C} 31 / 6$ > C39. Furthermore, they, according to their histones (as a function for transcriptional activity) might be ranked as follows: $\mathrm{C} 4612<\mathrm{C} 12 \mathrm{~T}<\mathrm{C} 39<\mathrm{C} 31 / 6<$ C92. These results, however, gave a strong evidence that the purified chromatin of the genotype C4612 displayed: 1 -low $\mathrm{Tm}$-value at $260 \mathrm{~nm}$ as well as at $280 \mathrm{~nm}$;

2-low histones, relative to DNA (1), and;

3-higher non-histones (percentage of total proteins) and; 4-high active fraction of genome for transcription. 
The results obtained from this part of the present investigation revealed, from a molecular genetics point of view, that these genotypes are different.

In conclusion, the present study revealed, that the tested genotypes, at the level of this study, are genetically different. In addition this molecular biomarker might be used and/or employed in evaluative purposes of breeding program for sugar beet.

\section{ACKNOWLEDGMENT}

The authors are appreciated to Dr. Magdy Saleh Professor of Genetics and Plant Breeding, of Agricultural Research Center (ARC), for providing the materials.

\section{REFERENCES}

Abdel-Aziz, S.M. and M.M.A. Reda, (2000). Osmotic adjustment for two wheat varieties. Egypt. J. Agric. Res., 78: 993-1004.

Abdel-Fattah R. S. (2002). Gene Expression In Relation To Heterochromatinization Phenomenon In Vicia faba. M.Sc. Thesis, Faculty of Agriculture University of Alexandria, A.R.E.

Bates, I.S., R.P. Waldren and I.D. Teare (1973). Rapid determination of free proline for water-stress studies. Plant and Soil, 39: 205207.

Bonner, J.; M. E. Dahmus, D. Fambrough, R. C. Huang, K. Marushige, and D. Y. H. Tuan. (1968). The biology of isolated chromatin, Sci., 159: 47-56.

Fellenberg G; (1974). Chromosomale Proteine Funkion und Bedeutung bei hoeheren Organismen; Stuttgart;Ulmer; Geb.mit SU;24 Abb. 15 Tab.;1;;Biologie;Biologie;5961.

Fellenberg, G. and U. Schomer (1975). Direct effect of IAA upon isolated chromatin of etiolated pea seelings. Zpflanzenphysiol. B and75. Meft 5, 449-456.

Freitas, J.B.S., R.M. Chagas, I.M.R. Almeida, F.R. Cavalcanti and JA.G. Silveira, (2001). Expression of physiological traits related to salt tolerance in two contrasting cowpea cultivars. Document Embrapa Meio-Norte, 56: 115-118.

Ghoulam, C., Foursy, A. and Fares, K. (2002). Effects of salt stress on growth, inorganic ions and proline accumulationin relation to osmotic adjustment in five sugar beet cultivars. Environ. Exp. Bot. 47: 39-50.
Gzik, A. (1996). Accumulation of proline and pattern of a-amino acids in sugar beet plants in response to osmotic, water and salt stress. Environ. Exp. Bot. 36: 29-38.

Heuer, B. and Z. Plaut, (1981). Photosynthesis and osmotic adjustment of two sugar beet cultivars grown under saline condition. J. Exp. Bot., 40: 437-440.

Khatab Amira M. (2001). Cytogenetical studies on Sugar beet. MSc. Fac. Agric. Alex Univ. Alexandia Egypt.

Lowry, 0. H., N. J. Rosebrough, A. L. Farr, and R. J. Randall. (1951). Protein measurement with the folinphenol reagent. J. Biol. Chem. 193: 265-275.

Martino, C., S. Delfine, R. Pizzuto, F. Lpreto and A. Fuggi, (2003). Free amino acids and glycine betaine in leaf osmoregulation of spinach responding to increasing salt stress. New Phytol., 158: 455-463.

Pakniyat H. and M. Armion (2007). Sodium and Proline Accumulation as Osmoregulations in Tolerance of Sugar Beet Genotypes to Salinity. Pakistan Journal of Biological Sciences 10 (22): 4081-4086.

Schondelmaier J. and C. Jung (1997). Chromosomal assignment of the nine linkage groups of sugar beet (Beta vulgaris L.) using primary trisomics. Theoretical and Applied Genetics 95, 590-6. Contact: Jung, C.; Inst. Pflanzenbau Pflanzenzuechtung, Christian-Albrechts-Univ. Kiel, Olshausenstr. 40, D-24118 Kiel, Germany.

Seehy, M.A. (1980). Physico-chemical properties of chromatin isolated from Vicia faba and Brassica olereacea var. botrytis. Ph.D. Thesis.

Seehy, M.A., S. Helmi; 1.1G. Shalabi and H. Ezzayat. (1990). Mercury and Paraquat dichloride induced alterations in chromatin physiochemical properties. Egypt. J. Genet. Cytol. 18: $147-158$.

Shabala, S., O. Babourina and I. Newman, (2000). Ion- specific mechanisms of osmoregulation in bean mesophyll cells. J. Exp. Bot., 51: 1243-1253.

Ueda, A., M. Kanechi, Y. Uno and N. Inagaki, (2003). Photosynthetic limitations of a halophyte sea aster (Aster tripolium $\mathrm{L}$.) under water stress and $\mathrm{NaCl}$ stress. J. Plant Res., 116: 65-70. 


\section{الملخص العربي}

\section{تفاوت وظيفة الجين والحواص الفيزيوكيماوية للكروماتين}

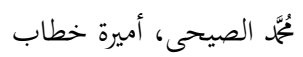

وأظهر التحليل الكيميائي لمكونات الكروماتين في صورة البروتين

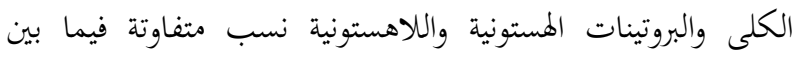

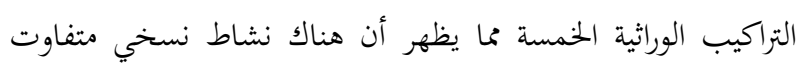

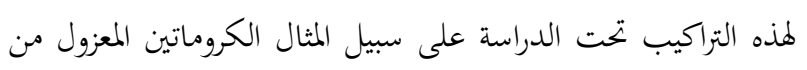

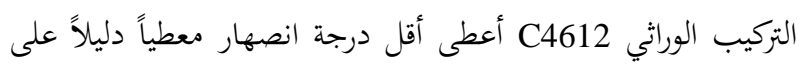

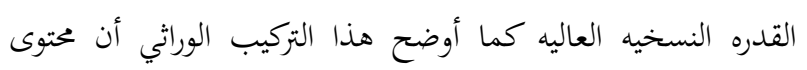

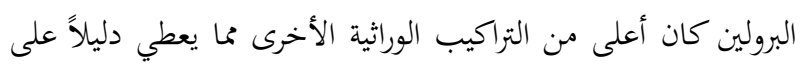

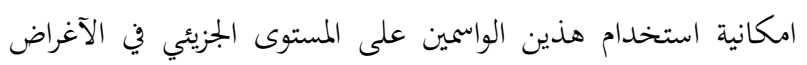

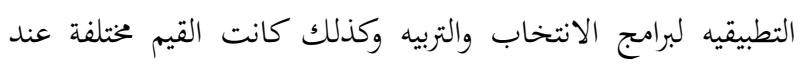

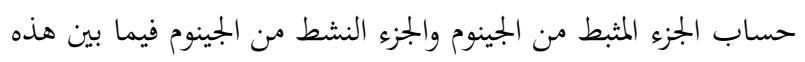

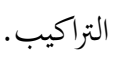

ومما سبق نستطيع القول أن التراكيب الوراثية الخمسة مختلفة وراثياً

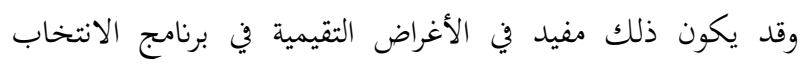

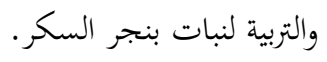

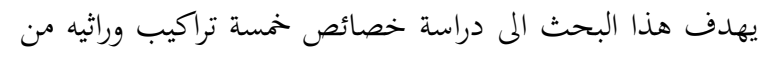

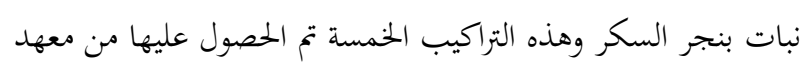
بحوث المحاصيل السكرية- مركز البحوث الزراعية.

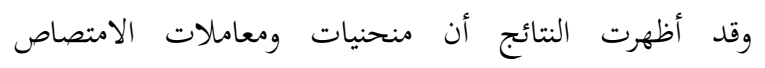

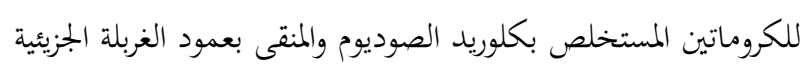

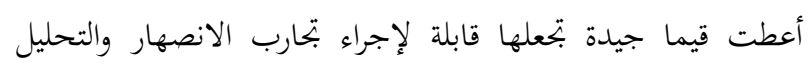
الكيموحيوي للمكونات. فقد أعطت درجة انصهار الكروماتين على

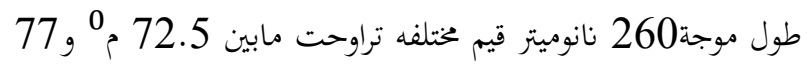

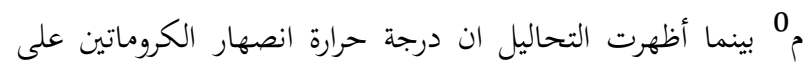

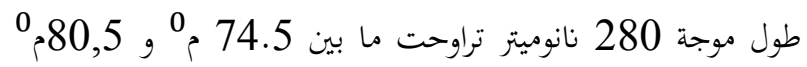
فيما بين التراكيب الوراثية الخمسة.

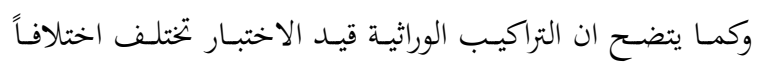

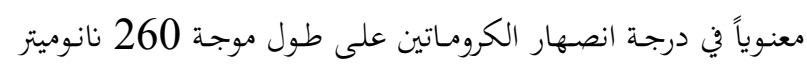

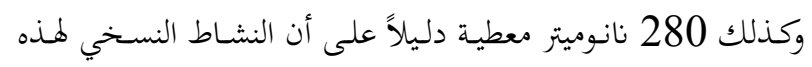

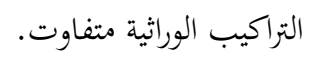

